\title{
PEMETAAN ANAK BERKEBUTUHAN KHUSUS PADA SEKOLAH INKLUSI MELALUI PROGRAM IDENTIFIKASI DAN ASESMEN
}

\author{
Wisnu Sulistyo Nugroho', ${ }^{1}$ Minsih $^{2}$ \\ Prodi Pendidikan Guru Sekolah Dasar, Universitas Muhammadiyah Surakarta ${ }^{1,2}$

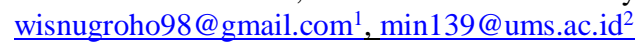

\section{INFO ARTIKEL}

Riwayat Artikel:

Diterima: 01-February-2021

Disetujui: 26-Maret-2021

\section{Kata Kunci:}

Identifikasi dan Asesmen

Pendidikan Inklusif

Siswa berkebutuhan khusus

ABSTRAK

\begin{abstract}
Abstrak: Penelitian ini bertujuan untuk mengetahui: 1) pelaksanaan program identifikasi dan asesmen siswa berkebutuhan khusus. 2) kendala dan solusi dari program. 3) dampak program bagi keberhasilan pendidikan inklusif. Jenis penelitian adalah kualitatif dengan desain studi kasus. Instrumen pengumpulan data berupa wawancara, dokumentasi dan observasi. Subjek dalam penelitian adalah kepala sekolah, wali kelas, GPK, siswa reguler, siswa berkebutuhan khusus dan orangtua ABK. Data diperoleh melalui triangulasi sumber dan triangulasi teknik. Teknik analisis data yang digunakan adalah reduksi data, penyajian data dan verifikasi data. Penelitian ini dilakukan di SD Al Firdaus Surakarta. Hasil penelitian menunjukkan: a) identifikasi dilaksanakan saat penerimaan peserta didik baru dan mutasi peserta didik dengan langkah menghimpun data kondisi anak melalui instrumen observasi dan wawancara dengan orang tua, menganalisis serta melakukan pemetaan kemudian melaporkan serta mendiskusikan hasil temuan kepada orangtua. Asesmen dilakukan dengan melibatkan psikolog, pedagog, okupasi terapi dan terapi wicara. Kurikulum yang digunakan sekolah adalah model modifikasi dengan mengubah materi beserta soal yang disesuaikan kemampuan anak, penempatan kelas dibagi menjadi dua, yaitu reguler dan pull out b) kendala berupa kehadiran orangtua guna membahas perkembangan anak. c) dengan dilaksanakannya program menunjukkan sekolah telah memenuhi komponen pendidikan inklusif selain itu pelaksanaan program berdampak positif bagi perkembangan akademik maupun sosial anak.
\end{abstract}

\begin{abstract}
This study aims to describe: 1) the implementation of the identification and assessment program for students with special needs. 2) constraints and solutions of the program. 3) the impact of the program for the success of inclusive education. The type of research is qualitative with a case study design. The data collection instruments were interviews, documentation and observation. The subjects in the study were the principal, homeroom teacher, GPK, regular students, students with special needs and parents of the students with special needs. Data obtained through triangulation of sources and triangulation of techniques. The data analysis technique used was data reduction, data presentation and data verification. This research was conducted at SD Al Firdaus Surakarta. The results showed: a) identification was carried out at the time of admission of new students and student mutations by collecting data on the child's condition through observation instruments and interviews with parents, analyzing and mapping, then reporting and discussing the findings to parents. The assessment is carried out by involving psychologists, pedagogues, occupational therapy and speech therapy. The curriculum used by the school is a modified model by changing the material and the questions that are adjusted to the child's abilities, class placement is divided into two, namely regular and pull out b) constraints in the form of parent presence to discuss child development. c) the implementation of the program shows that the school has fulfilled the inclusive education component. In addition, the implementation of the program has a positive impact on children's academic and social development.
\end{abstract}

\section{A. LATAR BELAKANG}

Setiap anak yang lahir di dunia ini memiliki hak yang sama untuk mendapatkan sebuah pendidikan yang layak yang dimana nantinya dapat digunakan untuk mengembangkan potensi yang dimiliki dalam diri mereka masing-masing tak terkecuali bagi mereka yang mempunyai kebutuhan khusus sekalipun. Hal tersebut sesuai dengan pendapat Minsih et al., (2019) yang menyatakan bahwa anak berkebutuhan khusus berhak mendapatkan peluang pendidikan bersama dengan anak normal lain pada umumnya. Anak berkebutuhan khusus merupakan anak yang mempunyai kelainan pada dirinya, sehingga mengakibatkan anak tersebut memiliki kebutuhan yang harus disesuaikan dengan karakteristinya (Daroni et al., 2018). 
Layanan pendidikan yang memberikan kesempatan bagi anak berkebutuhan khusus untuk dapat belajar bersama dengan anak normal pada umumnya yaitu melalui pendidikan inklusif. Pendidikan inklusif merupakan pendidikan yang memberikan kesempatan belajar kepada semua anak tanpa terkecuali anak-anak berkebutuhan khusus (Lestariningrum, 2017). Sedangkan Nugraheni et al., (2019) menyatakan pendidikan inklusif menggambarkan bahwa anak berkebutuhan khusus dididik di sekolah biasa bersama anak normal pada umumnya yang biasanya berkembang dengan pelayanan yang disesuaikan kebutuhan belajar dasar mereka. Melalui pendidikan inklusif diharapkan anak berkebutuhan khusus dapat belajar dan bersosial dalam satu lingkungan bersama anak normal lainnya. Selaras dengan hal tersebut Dewi, (2017) mengungkapkan bahwa pendidikan inklusif bertujuan memberikan kesempatan yang seluas-luasnya dalam pendidikan bagi peserta didik yang mempunyai kebutuhan tanpa deskriminasi sehingga mendapatkan layanan sesuai dengan kebutuhannya dan melaksanakan pendidikan yang menekankan pada keberagaman.

Dalam melaksanakan kegiatan pembelajaran, sekolah inklusi perlu mengetahui layanan pendidikan yang tepat untuk siswa berkebutuhan khususnya. Dalam hal ini berorientasi pada kebutuhan anak itu sendiri, layanan pendidikan ditekankan pada layanan individual. Maka dari itu sebelum dilaksanakannya kegiatan pemebelajaran sekolah perlu melakukan kegiatan berupa identifikasi dan asesmen bagi peserta didik berkebutuhan khusus guna mengetahui layanan serta bimbingan yang tepat bagi mereka. Sejalan dengan pendapat Dewi, (2018) yang menyatakan bahwa sebelum proses pemberian layanan pada anak berkebutuhan khusus, seorang praktisi pendidikan khusus harus melakukan tahapan identifikasi dan asesmen terlebih dahulu. Tahap ini bertujuan agar layanan yang diberikan untuk anak dapat tepat sasaran sesuai dengan karakteristik serta kebutuhan anak secara nyata.

Identifikasi merupakan kegiatan awal yang mendahului proses asesmen. Identifikasi adalah kegiatan mengenal atau menandai sesuatu, yang diartikan sebagai suatu proses penjaringan atau proses menemukan kasus yaitu menemukan anak yang mempunyai kelainan/masalah, atau proses pendektesian dini terhadap anak berkebutuhan khusus (Yuwono, 2015). Identifikasi bertujuan untuk menjaring atau menemukenali anak berkebutuhan khusus dari lingkungan yang heterogen untuk dicari karakteristik khusus yang dimiliki oleh masingmasing anak. Proses selanjutnya yaitu asesmen yang bertujuan untuk menggali informasi lebih lanjut tentang anak terkait kekurangan, potensi serta kebutuhan yang dimilikinya. Asesmen anak berkebutuhan khusus merupakan sebuah proses yang sistematis atau komperehensif atau secara menyeluruh dalam mencari permasalahan lebih lanjut untuk mengetahui apa yang menjadi hambatan, keunggulan dan kebutuhan individu (Dewi, 2018).

Identifikasi dan asesmen dilakukan oleh sekolah inklusi sebagai langkah untuk melakukan pemetaan bagi peserta didik yang yang mempunyai kelainan atau kebutuhan khusus. Pemetaan dilakukan untuk mengetahui jenis kebutuhan yang dimiliki oleh masing-masing anak sehingga dapat diketahui layanan pendidikan yang tepat bagi anak di sekolah. Hal tersebut sesuai dengan pendapat Minsih, (2020) yang menyatakan bahwa kegiatan identifikasi dan asesmen ditujukan untuk memetakan karakteristik siswa berkebutuhan khusus dan kemudian menentukan jenis tindakan yang akan diberikan.

Salah satu sekolah yang berbasis inklusi di Kota Surakarta adalah SD Al Firdaus. Sebagai penyelenggara sekolah inklusi yang menerima berbagai macam karakteristik anak, identifikasi dan asesmen untuk peserta didik berkebutuhan khusus sangatlah penting bagi SD Al Firdaus Surakarta guna mengetahui layanan serta bimbingan yang tepat bagi masing-masing peserta didik. Selain itu pelaksanaan identifikasi dan asesmen yang baik akan memudahkan guru dalam melakukan proses kegiatan pembelajaran nantinya. Pemenuhan kebutuhan pendidikan bagi anak berkebutuhan khusus dapat teralokasikan dengan tepat sesuai dengan kebutuhan mereka masing-masing Berdasarkan permasalahan diatas peneliti melakukan penelitian mengenai bagaimana pelaksanaan program identifikasi dan asesmen peserta didik berkebutuhan khusus yang telah berjalan di sekolah, kendala yang dihadapi dan solusinya, serta dampak bagi perkembangan peserta didik.

\section{B. METODE PENELITIAN}

Penelitian ini menggunakan jenis penelitian kualitatif dengan metode studi kasus. Penelitian ini dilakukan di SD Al Firdaus Surakarta dengan subjek penelitian adalah kepala sekolah, wali kelas, guru pendmping khusus, peserta didik reguler, peserta didik berkebutuhan khusus dan orang tua ABK. Teknik pengumpulan data dalam penelitian ini yaitu dengan cara wawancara, dokumentasi dan observasi. Keabsahan data yang digunakan dalam penelitian ini yaitu menggunakan triangulasi sumber dan triangulasi teknik. Triangulasi sumber berarti peneliti memperoleh data dari berbagai sumber yang berbeda dengan teknik yang sama. Sedangkan triangulasi teknik, data yang diperoleh dilapangan akan dibandingkan dan dilakukan pengecekan dari kegiatan wawancara, dokumentasi dan observasi yang dilakukan di SD Al Firdaus Surakarta. Teknik analisis data yang digunakan merupakan analisis data model Miles dan Huberman yaitu; 1) reduksi data, dilakukan oleh peneliti untuk merangkum, memilih gagasan utama terkait dengan analisis program identifikasi dan asesmen peserta didik berkebutuhan khusus. 2) penyajian data, adapun data yang disajikan meliputi data pelaksanaan program identifikasi dan asesmen, kendala dan solusi program dan dampak dari program terhadap keberhasilan pendidikan 
inklusif. 3) verifikasi data, hasil penelitian yang diperoleh dari tahap analisis data selanjutnya akan dikembangkan menjadi hasil serta dasar penarikan kesimpulan dalam penelitian ini.

\section{HASIL DAN PEMBAHASAN}

\section{Pelaksanaan Program Identifikasi}

SD Al Firdaus Surakarta merupakan salah satu sekolah berbasis inklusi di Kota Surakarta. SD Al Firdaus menerima calon peserta didik regular maupun berkebutuhan khusus tanpa adanya prasyarat tertentu. Sebelum menerima peserta didik baru di sekolah, SD Al Firdaus melakukan proses identifikasi dan asesmen terlebih dahulu kepada anak. Hal ini sejalan dengan pendapat Dewi, (2018) yang menyatakan bahwa sebelum proses pemberian layanan pada peserta didik berkebutuhan khusus, seorang praktisi pendidikan khusus harus melakukan langkah identifikasi dan asesmen terlebih dahulu. Sebelum diasesmen peserta didik diidentifikasi terlebih dahulu untuk melihat kasus atau kelaianan yang tampak secara kasar. Hal tersebut sesuai dengan pernyataan Yuwono, (2015) yang menyatakan identifikasi merupakan kegiatan awal yang mendahului proses asesmen. Identifikasi adalah kegiatan mengenal atau menandai sesuatu, yang dimaknai sebagai sebuah proses penjaringan atau proses menemukan kasus yaitu menemukan anak yang memiliki kelainan/masalah, atau proses pendektesian dini terhadap anak berkebutuhan khusus.

Dalam pelaksanaannya SD Al Firdaus melakukan identifikasi terhadap anak pada saat proses penerimaan peserta didik baru (PPDB) maupun peserta didik mutasi. Langkah tersebut cukup baik dilakukan oleh sekolah sehingga nantinya anak dengan indikasi berkebutuhan khusus bisa mudah dikenali. Sesuai dengan penelitian Indriawati, (2013) yang menyatakan bahwa proses identifikasi yang dilaksanakan di awal penerimaan peserta didik baru merupakan hal yang tepat untuk mendeteksi keberadaan ABK sedari awal sebelum pendidikan berlangsung. Pada penerimaan peserta didik baru untuk peserta didik dengan kebutuhan tuna netra berat (buta) sekolah belum bisa memberikan pelayanan dikarenakan tenaga ahli dan alat penunjang pembelajaran yang belum ada. Sedangkan untuk jenis kebutuhan tuna netra ringan (low vision) sekolah masih bisa untuk memberikan pelayanan pendidikan untuk anak.

Pada proses identifikasi, kegiatan menghimpun data kondisi anak dengan menggunakan dua buah instrumen yaitu, observasi dan pemetaan awal calon peserta didik baru. Identifikasi dilakukan oleh tim pemetaan SD Al Frdaus Surakarta. Tim pemetaan merupakan sebuah tim yang dibentuk oleh sekolah dengan beranggotakan guru, konselor dan terapis dimana mereka bertugas dalam proses melakukan identifikasi terhadap peserta didik berkebutuhan khusus. Selain menggunakan instrumen, tim pemetaan turut mengundang orang tua anak untuk melakukan proses wawancara untuk diberikan penjelasan bahwa SD Al Firdaus merupakan sekolah inklusi dimana sekolah selain menerima peserta didik regular pada umumnya sekolah juga menerima peserta didik dengan kebutuhan khusus. Dengan demikian diharapkan orang tua dapat memberikan informasi-informasi penting terkait karakterisktik atau kebutuhan yang ada pada anak.

Data terkait kondisi anak yang telah diidentifikasi selanjutnya akan dianalisis dan dilakukan pemetaan. Tim pemetaan selaku petugas identifikasi akan melakukan analisis dengan melihat data hasil dari penerapan instrumen observasi awal peserta didik baru. Instrumen observasi awal terdiri dari 16 aspek observasi. Keenambelas aspek yang ada dalam instrumen ini menilai dari segi kasar atau kondisi nyata yang tampak secara kasat mata mulai dari pengamatan secara fisik, mampu menunjukkan bagian anggota tubuh, mampu merespon instruksi, hingga menjaga keseimbangan. Hasil dari instrumen ini nantinya akan digunakan oleh sekolah untuk menentukan apakah anak masuk kedalam program regular atau inklusi. Pada setiap aspek observasi tersebut mempunyai penilaian dengan skor satu. Apabila jumlah skor menunjukkan dibawah angka 14 maka akan dipetakan sebagai peserta didik yang berindikasi atau mempunyai kebutuhan khusus.

Hasil analisis dan pemetaan dari proses identifikasi selanjutnya akan dilaporkan dengan melibatkan kepala sekolah, tim pemetaan dan orang tua. Tim pemetaan menunjukkan hasil temuan yang didapatkan selama proses identifikasi berlangsung. Anak dengan hasil dibawah standar yang telah ditetapkan pada instrumen observasi selanjutnya akan direkomendasikan oleh untuk dilakukan asesmen sebagai tindak lanjut identifikasi dengan melibatkan beberapa ahli untuk mengetahui lebih detail kebutuhan dan treatment yang tepat bagi anak nantinya saat pemberian layanan pendidikan di sekolah.

\section{Pelaksanaan Program Asesmen}

Tindak lanjut dari identifikasi yaitu asesmen yang bertujuan untuk menggali informasi lebih lanjut tentang anak terkait kekurangan, potensi serta kebutuhan yang dimilikinya sebagaimana menurut Yuwono, (2015) menjelaskan bahwa asesmen merupakan kegiatan professional yang dilakukan secara khusus menentukan diagnosa dari gangguan atau kelainan yang dialami seseorang. Tim pemetaan selaku petugas identifikasi selanjutnya akan menghubungi Puspalenta untuk mengkoordinasikan jadwal asesmen bagi anak yang memiliki skor dibawah standar pada proses identifikasi. Puspalenta sendiri merupakan sebuah pusat pendidikan, terapis dan pengembangan bakat anak yang masih berada dibawah naungan Yayasan Al Firdaus. Asesmen nantinya akan 
dilakukan oleh para tenaga ahli dianatarnya yaitu; psikolog, pedagog, okupasi terapi dan terapi wicara. Asesmen tersebut merupakan jenis asesmen formal dimana dalam pelaksanannnya melibatkan para tenaga ahli dibidangnya, sebagaimana diungkapkan oleh Dewi, (2018: 23) yang mengungkapkan bahwa asesmen formal merupakan asesmen bagi anak berkebutuhan khusus yang dalam prosedurnya dilakukan oleh seorang profesioanal. Pada penelitian ini contoh instrumen asesmen yang digunakan oleh sekolah belum bisa diperoleh dikarenakan pihak sekolah belum bisa memberikan dengan alasan bahwa instrumen asesmen merupakan hak dari masing-masing tenaga ahli terkait. Berdasarkan hasil pernyataan dari kepala sekolah, diketahui bahwa sekolah tidak melakukan screening secara berkala kepada anak, akan tetapi screening dilakukan dari segi interaksi antara guru dengan peserta didik selama proses pembelajaran. Apabila ditemukan kasus baru maka akan dilakukan asesmen ulang dengan para tenaga ahli.

Diagnosis dari para tenaga ahli kemudian akan dikonsultasikan kembali kepada orang tua dengan mempertimbangkan kebutuhan belajar yang diperlukan oleh anak nanti selama proses pembelajaran disekolah. Selanjutnya GPK, wali kelas dan orang tua membuat program pembelajaran individual (PPI) yang disusun saat awal pembelajaran. PPI tersebut berisi target yang harus dicapai oleh anak selama pemebelajaran serta untuk kompetensi dasar (KD) dalam pembelajarannya disesuiakan dengan kemampuan dan kebutuhan masing-masing anak. Sejalan dengan pendapat Sari Rudiyanti dalam (Makhfiroh, 2017) yang menyatakan Program Pembelajaran Individual "Individualized Educational Program/IEP" yang berarti rancangan program guna menentukan kebutuhan pendidikan yang unik untuk peserta didik berkebutuhan khusus.

Hasil dari diaognosis akan menjadi acuan guru dalam menentukan jenis kurikulum yang akan diajarkan bagi peserta didik sebelum dilakukan pembelajaran. Menurut Friend \& Bursuck, (2015) penempatan kurikulum meliputi keputusan mengenai level yang akan dipilih untuk memulai pengajaran siswa. Penempatan kurikulum bagi peserta didik berkebutuhan khusus di SD Al Firdaus dibagi menjadi dua. Untuk anak yang masih mampu mengikuti program regular maka akan diikutkan program regular. Sedangkan untuk anak yang tidak bisa mengikuti program regular akan dimodifikasi kurikulumnya. Modifikasi yang dilakukan berupa modifikasi materi dan soal yang dibuat oleh GPK dengan wali kelas yang disesuaikan kemampuan dari anak. Sebagaimana yang dijelaskan Rusmiyati, (2017) model modifikasi kurikulum yaitu merubah untuk disesuaikan dengan kondisi, kebutuhan, dan kemampuan anak berkebutuhan khusus. Modifikasi terjadi pada empat komponen utama pembelajaran, yaitu: tujuan, materi, proses dan evaluasi. Dari hasil modifikasi kurikulum tersebut akan menentukan penempatan kelas bagi perserta didik berkebutuhan khusus.

Model penempatan kelas bagi peserta didik berkebutuhan khusus di SD Al Firdaus dibagi menjadi dua yaitu, anak yang mengikuti pembelajaran di dalam kelas reguler dan di kelas terpisah atau pull out. Mereka yang mengikuti pull out merupakan anak yang memiliki kebutuhan tertentu seperti down syndrome, autis dan retardasi mental. Sedangkan melalui hasil observasi diketahui bahwa selama masa pandemi Covid-19 pendampingan kepada peserta didik berkebutuhan khusus dilakukan secara home visit oleh GPK. Home visit dilakukan oleh GPK terhadap peserta didik berkebutuhan khusus yang bertempat tinggal tidak jauh dari sekolah, sedangkan untuk siswa yang rumahnya cukup jauh dari sekolah akan dilakukan pendampingan secara individual di sekolah. Peserta didik berkebutuhan khusus mendapatkan jadwal bimbingan tiga hari dalam seminggu dengan durasi dua sampai tiga jam.

Evaluasi pengajaran dilakukan guru untuk menentukan tindak lanjut dari pembelajaran yang telah diberikan pada anak. Sebagaimana menurut Friend \& Bursuck, (2015) mengungkapkan dalam evaluasi pengajaran meliputi keputusan untuk melanjutkan atau mengubah prosedur pengajaran yang telah diterapkan pada siswa. Keputusan dibuat dengan memantau kemajuan secara cermat. Evaluasi yang dilakukan oleh guru yaitu dengan melihat kondisi dan tingkah laku anak setelah dilakukan pembelajaran. Guru akan melihat kondisi anak apakah masih sering menunjukkan kondisi yang kurang baik seperti tantrum yang kemudian akan dikonsultasikan dengan GPK dan terapisnya. Sedangkan dari hasil observasi, GPK melakukan evaluasi diakhir pendampingan individual dengan mengulas kembali materi yang diberikan melalui beberapa pertanyaan kepada anak.

Kemajuan atau perkembangan yang dialami peserta didik dilihat sekolah dengan melakukan pemantauan secara berkala. SD Al Firdaus Surakarta melakukan pemantauan dengan menggunakan result student smart plan. Student Smart Plan sendiri merupakan sebuah rencana pembelajaran serupa dengan RPP yang disusun pada awal semester baru. Pada Student Smart Plan ini terdapat target serta langkah yang harus dilakukan oleh peserta didik guna mencapai target mereka selama tiga bulan kedepan. Student smart plan yang dibuat pada saat awal semester juga berguna sebagai pemantau perkembangan yang telah terjadi pada anak. Pemantauan menggunakan result student smart plan ini dilihat setiap tiga bulan sekali pada akhir pembelajaran. Bentuk pemantauan untuk anak berkebutuhan khusus yang lainnya yaitu lewat buku penghubung yang dilporkan setiap hari oleh GPK kepada orang tua anak.

Evaluasi program dilakukan oleh wali kelas dan GPK setelah mengetahui kemajuan dan perkembangan yang dialami oleh anak untuk menentukan kelanjutan dari program yang telah diterapkan. Sebagaimana yang dikemukakan Friend \& Bursuck, (2015) dimana evaluasi meliputi keputusan untuk menghentikan, melanjutkan, 
atau memodifikasi program pendidikan khusus seorang peserta didik. Bentuk evaluasi program yang dilaksanakan oleh SD Al Firdaus yaitu, dengan menggunakan Student Smart Plan. Setelah tiga bulan berjalannya pembelajaran sekolah akan melakukan evaluasi dalam forum Three Way Conference (TWC) yang melibatkan antara guru, orang tua beserta anak guna membahas perkembangan dan target yang belum bisa diraih oleh anak selama tiga bulan. Dari evaluasi tersebut kemudian akan dilakukan follow up pada tiga bulan berikutnya, dan akan berkelanjutan seterusnya.

\section{Kendala dan Solusi Pelaksanaan Program Identifikasi dan Asesmen}

Berdasarkan data yang diperoleh diketahui beberapa kendala yang dihadapi oleh SD Al Firdaus Surakarta dalam pelaksanaan program identifikasi dan asesmen untuk anak berkebutuhan khusus diantaranya yaitu, campur tangan orang tua yang mempengaruhi kevalidan data pada proses identifikasi dan dijumpainya beberapa orang tua yang cenderung menutupi kekurangan pada anaknya. Selain itu wali kelas juga menyampaikan bahwa kendala yang kadang dialami oleh sekolah yaitu saat sekolah susah untuk menghadirkan orang tua di sekolah guna membahas perkembangan anaknya. Hal tersebut sesuai dengan ungkapan Triwardhani et al., (2020) mendorong keterlibatan orang tua di sekolah sangat tidak mudah. Hal yang umum terjadi orang tua siswa hanya datang pada saat menerima rapor atau ketika anaknya bermasalah di sekolah. Diadha, (2015) juga mengungkapkan bahwa keterlibatan orang tua dalam pendidikan anak merupakan hal mutlak yang harus dilakukan padaa setiap lembaga pendidikan sehingga mampu mengoptimalkan pencapaian perkembangan dan tujuan progam pendidikan anak. Sedangkan Pusitaningtyas, (2016) menjelaskan bahwa komunikasi yang efektif antara orang tua dan guru dibutuhkan dalam rangka menyamakan persepsi kedua belah pihak tentang hal yang dibutuhkan dalam pendidikan anak.

Dalam mengatasi hal tersebut SD Al Firdaus Surakarta berusaha menghadirkan komunikasi secara berulang dengan orang tua. Sekolah menghadirkan kegiatan Three Way Conference yang dilaksanakan setiap tiga bulan sekali sebagai upaya membangun komunikasi dengan orang tua dalam usaha memberikan pelayanan yang tepat bagi para siswa dengan pertimbangan orang tua siswa sendiri. Selain itu GPK selaku pendamping siswa berkebutuhan khusus selalu menjaga komunikasi setiap harinya dengan orang tua melalui buku pengubung untuk selalu mendengar saran dan masukan yang ada. Langkah tersebut sesuai dengan pendapat Triwardhani et al., (2020) yang mengungkapkan bahwa menjaga relasi antara orang tua dengan guru sangat tidak mudah. Komunikasi yang berkelanjutan harus selalu dijaga, respons dari orang tua selalu ditanggapi, ide-ide yang disampaikan haus diakomodir dengan baik.

\section{Dampak Program Bagi Keberhasilan Pendidikan Inklusif}

Program identifikasi dan asesmen bagi peserta didik berkebutuhan khusus yang telah dilaksanakan SD Al Firdaus Surakarta menunjukkan bahwa sekolah telah memenuhi komponen dalam pendidikan inklusif, sebagaimana yang diungkapkan oleh Minsih, (2020) bahwa komponen dalam pendidikan inklusif harus memuat aktivitas yang dimulai dengan aspek identifikasi dan asesmen, PPI, kurikulum modifikasi, ketersediaan GPK dan evaluasi pembelajaran. Begitu juga dengan komponen PPI, kurikulum, dan evaluasi pembelajaran yang telah diterapkan dengan cukup baik oleh sekolah. Sedangkan untuk ketersediaan GPK, diketahui bahwa sekolah saat ini memiliki GPK yang berjumlah 28 orang.

Pendidikan dari guru merupakan hal yang perlu diperhatikan sebelum memberikan pembelajaran bagi anak berkebutuhan khusus. Hal tersebut sesuai dengan pendapat Minsih et al., (2018) yang menyatakan latar belakang dari pendidikan guru merupakan salah satu indikator penentu keberhasilan pendidikan inklusif. Berdasarkan hasil wawancara dengan kepala sekolah diketahui bahwa tidak semua GPK di SD Al Firdaus Surakarta berlatar belakang pendidikan luar biasa (PLB) melainkan dari berbagai macam latar pendidikan yang berbeda. Akan tetapi meskipun tidak semua GPK berlatar belakang PLB, sekolah memberikan pelatihan mengenai pendidikan inklusif kepada GPK sebelum terjun ke lapangan. Selain itu sekolah juga mempunyai kegiatan bagi GPK yang bernama Personal Development (PD) yang dijadwalkan setiap hari Jumat dimana kegiatan tersebut berupa sosialisasi, sharing serta pelatihan dalam menangani anak berkebutuhan khusus.

Sarana dan prasarana juga menjadi indikator utama dalam pendidikan inklusif. Sebagaimana hasil penelitian Adeniyi et al., (2015) yang mengungkapkan bahwa fasilitas/sarana dan prasarana memiliki indeks persentase paling yang tinggi dalam mempengaruhi keberhasilan pendidikan inklusif di Nigeria. Dari hasil observasi dan dokumentasi yang dilakukan di SD Al Firdaus Surakarta menunjukkan bahwa sarana dan prasarana yang dimiliki sekolah cukup baik dan memadai. Dalam menunjang anak berkebutuhan khusus sekolah telah menyediakan ruang terapi, ruang inklusi (pull out) dan ruang konseling. Media dan alat pembelajaran yang ada sudah cukup komplit baik untuk membaca, menulis, menghitung, melatih motorik halus, motorik kasar dan keseimbangan peserta didik berkebutuhan khusus. Akan tetapi untuk media yang menunjang pembelajaran anak tuna netra (buta) seperti tulisan dan buku braille belum tersedia di sekolah. 
Kerjasama atau kolaborasi dengan pihak lain di luar sekolah menjadi hal yang penting dalam menunjang pendidikan inklusif. Sesuai dengan pernyataan Sukinah, (2010) bahwa guru dituntut melakukan kolaborasi dengan profesi atau sumberdaya lain dalam perencanaan, pelaksanaan dan evaluasi. Kolaborasi yang dibangaun oleh SD Al Firdaus Surakarta sudah menunjukkan hal yang baik. Dimana dalam pelaksanaan asesmen, treatment dan diagnosis untuk peserta didik berkebutuhan khusus sekolah mempunyai pusat layanan klinis sendiri bernama Puspalenta dimana disana terdapat beberapa tenaga ahli yang mencakup psikolog, pedagog, okupasi terapi dan terapi wicara. Selain itu kolaborasi sekolah dengan orang tua ditunjukkan melalui penyususnan program bagi masing-masing anak berkebutuhan khusus dimana orang tua diberikan kesempatan untuk mengetahui dan memberikan masukan terkait program pembelajaran yang disusun untuk anaknya. Kolaborasi dengan orang tua tersebut terlaksana dalam forum Three Way Conference yang dilaksanakan tiga bulan sekali untuk memantau dan mengevaluasi perkembangan yang ada pada anak.

Dampak program bagi anak juga menunjukkan hal yang baik. Hasil wawancara dengan orang tua peserta didik berkebutuhan khusus, keduanya mengungkapkan bahwa perkembangan akademik dan sosial pada anaknya telah mengalami perkembangan yang cukup baik, mulai dari kemandirian yang mulai meningkat, keberanian dalam bersosial dengan orang lain hingga mulai mampu membaca dan menulis dengan lancar. Selain itu orang tua mengungkapkan bahwa pembelajaran anak dimudahkan dengan adanya program tersendiri bagi anak yang tersusun dalam Program Pembelajaran Individual (PPI) dan student smart plan dimana program-program tersebut menyesuaikan kemampuan dari anak. Hal tersebut sesuai dengan penelitian dari Asiyah, (2018) yang mengungkapkan bahwa adanya Program Pembelajaran Individual (PPI) berdampak positif dalam memudahkan anak belajar karena bahan ajar yang digunakan disesuaikan dengan kemampuan dan kebutuhannya sehingga aspek akademik anak dapat berkembang dan mendapatkan hasil maksimal. Keberhasilan lainnya ditunjukkan sekolah dengan adanya salah satu peserta didik berkebutuhan khusus yang berprestasi dengan menjuarai lomba bercerita tingkat nasional pada tahun 2018.

Hasil wawancara dari peserta didik reguler maupun berkebutuhan khusus juga menunjukkan bahwa mereka tidak mempunyai masalah dalam bersosial maupun bermain bersama di lingkungan sekolah. Selain itu di dalam profil pembelajaran kurikulum internasional yang diterapkan oleh SD Al Firdaus menyisipkan poin "Caring" dimana peserta didik dibiasakan untuk penduli dan menghargai perbedaan. Dalam pelaksanaannya sendiri kepala sekolah menuturkan bahwa sekolah setiap harinya mengadakan briefing pagi dan siang untuk memberikan refleksi dan motivasi bagi peserta didik untuk menjadi pribadi yang peduli baik bagi sesama manusia maupun lingkungan. Selaras dengan hal tersebut, Purnando (2018) menyatakan bahwa anak-anak yang menempuh pendidikan di sekolah inklusi, baik normal maupun berkebutuhan khusus, dididik untuk saling menghargai keberagaman masing-masing.

\section{SIMPULAN DAN SARAN}

Berdasarkan hasil penelitian yang dilakukan dapat diperoleh kesimpulan bahwa program identifikasi dilaksanakan oleh sekolah saat penerimaan peserta didik baru dan mutasi peserta didik. Dalam menghimpun data kondisi anak sekolah menggunakan instrumen observasi dan wawancara dengan orang tua. Selanjutnya sekolah melakukan analisis dan pemetan kepada anak yang berindikasi mempunyai kebutuhan khusus. Temuan dari hasil identifikasi kemudian akan di laporkan dan dikonsultasikan kepada orang tua yang selanjutnya akan direkomendasikan untuk melakukan penjadwalan asesmen guna mengetahui lebih jauh detail kebutuhan serta treatment yang tepat bagi anak. Dalam penerimaan calon peserta didik baru berkebutuhan khusus sekolah menerima berbagai kriteria anak dengan pengecualian untuk peserta didik dengan kebutuhan tuna netra berat (buta) dikarenakan belum adanya tenaga ahli serta media yang mendukung di sekolah. Asesmen formal dilakukan sekolah dengan melibatkan tenaga ahli diantaranya psikolog, pedagog, terapi wicara dan okupasi terapi. Model kurikulum yang digunakan oleh sekolah adalah model modifikasi dengan mengubah materi beserta soal yang disesuaikan kemampuan anak, model penempatan kelas dibagi menjadi dua, yaitu reguler dan pull out.

Kendala yang dihadapi sekolah yaitu, berupa kecenderungan orang tua yang menutupi kebutuhan anak pada saat proses identifikasi serta kehadiran orang tua guna membahas perkembangan anak. Dalam mengatasi hal tersebut sekolah selalu berusaha menjaga komunikasi dengan orang tua anak diantaranya dengan menghadirkan forum Three Way Conference selain itu GPK selaku pendamping anak selalu menjaga komunikasi dengan orang tua melalui buku penghubung yang dibuat setiap hari. Dengan dilaksanakannya program identifikasi dan asesmen menunjukkan bahwa sekolah telah memenuhi komponen pendidikan inklusif selain itu pelaksanaan program menunjukkan dampak positif bagi perkembangan akademik maupun sosial pada anak.

Saran yang diberikan peneliti kepada sekolah terkait pelaksanaan program identifikasi dan asesmen yaitu, dalam penggunaan instrumen identifikasi peserta didik berkebutuhan khusus untuk kedepannya dapat dibuat lebih rinci kembali dengan menambahkan indikator gejala-gejala yang berbeda untuk setiap jenis kebutuhan khusus anak, menambah tenaga ahli serta alat/media yang mendukung bagi anak tuna netra berat (buta) di sekolah dan 
melakukan screening secara berkala bagi peserta didik agar jenis hambatan atau kebutuhan pada anak dapat diketahui dengan baik.

\section{DAFTAR RUJUKAN}

[1] Adeniyi, Olufemi, S., Josiah, O., \& Kehinde, O. 2015. Determinants of Successful Inclusive Education Practice in Lagos State Nigeria. World Journal Education, 5 (2), 26-32. https://doi.org/10.5430/wje.v5n2p26

[2] Asiyah, D. 2018. Dampak Pola Pembelajaran Sekolah Inklusi terhadap Anak Berkebutuhan Khusus. Prophetic, 1 (1), 69-82.

[3] Daroni, Ali, G., Abdul, \& Sunardi. 2018. Impact of Parent's Divorce on Children's Education for Disability Kids. Indonesian Journal of Disability Studies (IJDS), 5(1), 1-9.

[4] Dewi, D. P. 2018. Asesmen Sebagai Upaya Tindak Lanjut Kegiatan Identifikasi Terhadap Anak Berkebutuhan Khusus. Wahana, 70(1), 17-24.

[5] Dewi, N. K. 2017. Manfaat Program Pendidikan Inklusi Untuk AUD. Jurnal Pendidikan Anak, 6(1),12-19.

[6] Diadha, R. 2015. Keterlibatan Orang tua Dalam Pendidikan Anak Usia Dini Di Taman Kanak-kanak. Jurnal Ilmu Pendidikan Dan Pengajaran, 2(1), 61-71.

[7] Friend, M., \& Bursuck, W. 2015. Menuju Pendidikan Inklusi Panduan Praktis untuk Mengajar Edisi Ketujuh (7th ed.). Pustaka Belajar.

[8] Indriawati, P. 2013. Implementasi Kebijakan Tugas Guru Pembimbing Khusus pada Pendidikan Inklusif di SD Negeri se-Kecamatan Junrejo Batu. Jurnal Kebijakan Dan Pengembangan Pendidikan, 1(1), 49-55.

[9] Lestariningrum, A. 2017. Implementasi Pendidikan Inklusif Untuk Anak Usia Dini Di Kota Kediri (Studi Pada PAUD Inklusif YBPK Semampir, Kecamatan Kota, Kediri). Jurnal CARE (Children Advisory Research and Education), 4 (2), 53-68.

[10] Makhfiroh, K. M. 2017. Layanan Bimbingan Belajar Anak Berkebutuhan Khusus Di Sekolah Inklusi Sekolah Dasar Negeri Sumbersari 2 Kota Malang.

[11] Minsih, M., Amalia, N., P. H., S., Suparno, S., \& Mujahid, I. 2019. Mapping of New Student Admission in Inclusive Education Learning at Al-Firdaus Elementary School Surakarta. 296(Icsie 2018), 24-28. https://doi.org/10.2991/icsie-18.2019.5

[12] Minsih, Slamet, Suparno, \& Imam. 2018. Equality Of Learning For Children With Special Needs : Case Studies At The Ele-mentary School Level. Opcion, Ano, 34(86), 2667-2674.

[13] Minsih. 2020. Pendidikan Inklusif Sekolah Dasar Merangkul Perbedaan dalam Kebersamaan. Muhammadiyah University Press.

[14] Nugraheni, P. P., Salim, A., \& Hidayatullah, M. F. 2019. Teachers' Knowledge and Understanding Toward Learning-Friendly Education for Children with Disabilities in Inclusive School. International Journal of Multicultural and Multireligious Understanding, 6(1), 60. https://doi.org/10.18415/ijmmu.v6i1.490

[15] Purnando, R. 2018. Interaksi sosial anak berkebutuhan khusus di sekolah alam bengkulu mahira. Institut Agama Islam Negeri (IAIN) Bengkulu.

[16] Pusitaningtyas, A. 2016. Pengaruh Komunikasi Orang tua dan Guru Terhadap Kreativitas Siswa. International Seminar on Generating Knowledge Through Research, 1 (14), 935-942.

[17] Rusmiyati. 2017. Anak Berkebutuhan Khusus (ABK) Bukan Sampah dan Musibah di Sekolah Penyelenggara Pendidikan Inklusif (SPPI). Literasi, VIII (2), 119-127.

[18] Sukinah. 2010. Manajemen Strategik Implementasi Pendidikan Inklusif. Jurnal Pendidikan Khusus, $7(2), 40-51$.

[19] Triwardhani, I. J., Trigartanti, W., Rachmawati, I., \& Putra, R. P. 2020. Strategi Guru Dalam Membangun Komunikasi Dengan Orang Tua Siswa di Sekolah. Jurnal Kajian Komunikasi, 8(1), 99-113.

[20] Yuwono, I. 2015. Identifikasi Dan Asesmen Anak Berkebutuhan Khusus (Setting Pendidikan Inklusi) (N. Muniroh (ed.). Pustaka Banua. 